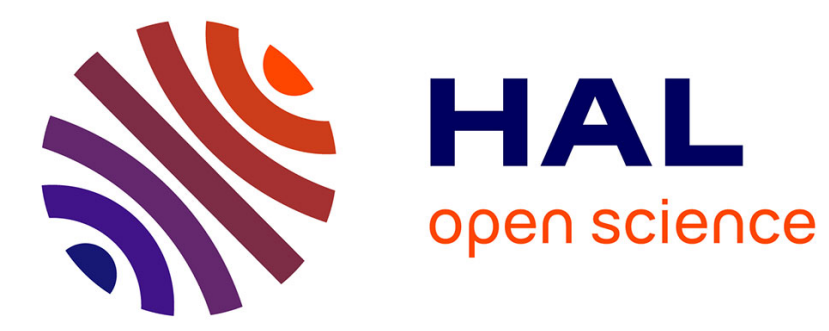

\title{
Le goût des autres: Gentrification told by children
}

Jean-Yves Authier, Sonia Lehman-Frisch

\section{To cite this version:}

Jean-Yves Authier, Sonia Lehman-Frisch. Le goût des autres: Gentrification told by children. Urban Studies, 2013, 50 (3), pp.994-1010. 10.1177/0042098012465127 . hal-01401640

\section{HAL Id: hal-01401640 \\ https://hal.parisnanterre.fr/hal-01401640}

Submitted on 5 Dec 2016

HAL is a multi-disciplinary open access archive for the deposit and dissemination of scientific research documents, whether they are published or not. The documents may come from teaching and research institutions in France or abroad, or from public or private research centers.
L'archive ouverte pluridisciplinaire HAL, est destinée au dépôt et à la diffusion de documents scientifiques de niveau recherche, publiés ou non, émanant des établissements d'enseignement et de recherche français ou étrangers, des laboratoires publics ou privés. 


\title{
Le goût des autres. Gentrification told by children
}

\author{
Sonia Lehman-Frisch
}

\section{Abstract :}

If the gentrification literature has considerably expanded in the last decades, few works have attempted to understand the relationship between the "gentrifying" households of the middle classes and the "gentrified" households of the working classes, as seen through the eyes of the children. However, in many cases, gentrification involves families, and children are then actively involved in the local cohabitation relationship. This is the issue at the heart of this article: to examine the experiences of social diversity of children from different social backgrounds aged 9 to 11, living in a gentrified neighbourhood in Paris. We will do so by investigating successively their representations of and activities within the neighbourhood, their usage of a public space which occupies a key position (the local park), and their sociability. On the basis of these analyses, we will show how, within this gentrified neighbourhood, the children "play" with social diversity. 


\section{Le goût des autres. Gentrification told by children}

Since the pioneering work of Ruth Glass in the 1960's on the social revitalisation of an old working class neighbourhood in the centre of London "invaded" by housing belonging to the middle and upper middle classes [Glass, 1964], "gentrification" has been the subject of numerous works [Atkinson and Bridge (dir.), 2005; Lees, Slater and Wyly, 2008; Authier and Bidou-Zachariasen (dir.), 2008]. Within this group, many authors have been interested in the residential co-existence in these areas, which, considering the more and more prominent social divisions in the urban spaces of the inner city, constitute relatively rare - and lasting - examples of social diversity ${ }^{\text {ii }}$. Yet in these gentrified (or gentrifying) neighbourhoods few works have attempted to understand the relationship between the "gentrifying" households of the middle and upper-middle classes and the "gentrified" households of the working classes, as seen through the eyes of the children. Gentrification is certainly not always a tale of families and children. In some contexts, it concerns mainly single people or young childless couples [Dansereau, 1985; Van Criekingen, 2008]. But many circumstances of gentrification involve family households from diverse social backgrounds.

In these cases, children are actively involved in the relationships of residential coexistence. Like their parents, they are residents of these neighbourhoods, examples of the ways and means of co-existence. Moreover, as these ways and means are more or less defined by the parents (Valentine, 2004) they are clear indicators of the 
relationship that the parents maintain with the social diversity of their neighbourhood. Conversely, through their particular uses of the neighbourhood and their social interaction, children can also influence their parents' co-existence relationships. Analysing the place and role of children in co-existence relationships in gentrified neighbourhoods can, therefore, allow us to develop our knowledge of residential co-existence in circumstances of gentrification, and, in turn, of gentrification.

This is both the object and the issue at the heart of this article: to examine the experiences of social diversity of children from different social backgrounds aged 9 to 11 , living in a gentrified neighbourhood in Paris, the Batignolles. iii What connection do these children have with their socially diverse neighbourhood? How do they perceive the other children and residents that make up their neighbourhood? What uses do they make of their neighbourhood? What is the relationship between children of middle (or upper-middle) class families and those of the working class? In this neighbourhood, do we notice a "nice mix of children" [Vincent, Ball, 2006: 59] or, on the contrary, a reluctance to mix? How do the parents involve themselves in their children's practices and in their sociability?

To clarify our approach, we will firstly cover the literature relating to gentrification and children. We will then introduce the Batignolles neighbourhood, the school and the class which these particular children attend, explaining our methodology. Finally, 
we will analyse the social diversity experiences of these children, by examining successively their representations of and activities within the neighbourhood, their usage of a public space which occupies a key local position (Cardinet Park), and their sociability. On the basis of these analyses, we will demonstrate how, within this gentrified neighbourhood, the children "play" with social diversity.

\section{The children: poor parents from works on gentrification}

As a study entitled La gentrification à Paris intra-muros recently noted, "the place of families and children in gentrification has (...) scarcely been touched on until now" [Clerval, 2008, p.43]. Gentrification processes were first related to artists, students, etc., who were non family households most of the time, which explains why studies have not yet turned to families and their children. When they have, authors have tended, in different types of gentrified neighbourhoods, to analyse the schooling strategies of middle class families, either within work focused on gentrification [Butler with Robson, 2003; Clerval, 2008; Collet, 2010], or within a wider range of works on the educational choices of the middle classes [Oberti, 2007; Van Zanten, 2009]. In a convergent way, these studies show that these families who often vaunt social

diversity and for whom the school constitutes an important factor in social reproduction and an accurate gauge of their relationship to social diversity, have tended to favour a "rationale of protection", demonstrated alternatively by a 
"strategy of avoidance" or by a "strategy of colonisation" of the neighbourhood's state schools. Simultaneously, behind these general trends the research reveals varied schooling strategies closely tied to the families' links to their neighbourhood, alternating between closed and open social attitudes towards those "different from themselves", according to the context, to the gentrifiers and, also, to the age of the children. These works therefore demonstrate that the new generation of gentrifiers are more likely to send their children to school outside the neighbourhood and are less open to social diversity than the "pioneers", that middle class households working in the public sector make use of public establishments more than private sector families, and that the "school avoidance" tendency (of the neighbourhood's public establishments) is more common amongst secondary school children than those in primary education.

In a similar perspective, other researchers have explored the early childcare support choices made by middle class parents in gentrified neighbourhoods. One such study was made by Carol Vincent and Stephen J. Ball [2006] in two gentrified areas of London: Stoke Newington and Battersea. Here, the authors questioned middle class men and women with children aged 0 to 5 on their choices of babysitter or nanny, of childcare, of playgroup and of primary school. As in the aforementioned research, their analysis highlights the differences between members of the middle classes and between the neighbourhoods, with regards to the local and interpersonal dimensions of the middle class. In Stoke Newington, where social diversity is extensive, middle 
class families, often working in public services, in the media or in associations, find types of childcare relatively open to social diversity. In contrast, in the more gentrified Battersea area, where social diversity is more relative and where the gentrifying population comprises mainly professionals from the City, choices of childcare amongst the middle classes point to, and reveal, an "ethnic and class-based insularity".

Some authors have studied the residential choices of middle class families who, rather than settling in the suburbs as is usually the case, prefer to live in the gentrified neighbourhoods in the central city [Karsten, 2003, 2007]. In the different contexts observed (Rotterdam, Amsterdam), the motivation for couples to raise their children in these neighbourhoods is very close to that of other, childless gentrifiers: to reduce the time and the cost of transport, to enjoy the social and cultural aspects of the city, and to live in an area with a diverse population of varying lifestyles. But here again, as vaunted as this "diversity" may be, the "social anchorage" of these families appears limited: their social networks are in fact composed of individuals and families of similar class, ethnicity, family situation and values in urban life. And in the make-up of these networks, children play an important role: they link these families who live in close proximity, those links becoming opportunities for mutual help and for the exchange of services and advice. Equally, as in previously mentioned studies, the analyses reveal variations between the different contexts. In Rotterdam, for example, the social networks of middle class families are less mono-ethnic than in Amsterdam. 
Within this literature, researchers have therefore focused their attention on middle class families more than working class families, no doubt in part because the latter are harder to investigate [Clerval, 2008; Oberti, 2007]. This lack of studies is problematic because working-class families are also residents of these gentrified neighbourhoods in their own right. Furthermore, these authors have studied coexistence relationships more between parents than between children, arising from surveys conducted amongst those parents, and not the children themselves, who are themselves a legitimate category of residents of these neighbourhoods. The authors have also favoured the question of schooling (and educational choices), at the expense of a wider and more systematic analysis of co-existence relationships in the various public areas of gentrified neighbourhoods (shops, parks, after school clubs, etc.). Similarly, these works do not add a great deal to our knowledge of the ways and means of living together of middle class and working class children in gentrified neighbourhoods, outside of the school walls. ${ }^{\text {iv }}$

However, within Children's Studies, many researchers have focused on children's daily lives in non-gentrified urban areas: they have shown the changing nature of children's urban practices, their decreasing presence in public spaces, their loss of spatial freedom and the institutionalization and the insularization of their uses [Holloway, Valentine, 2000; Chawla, 2002; Christensen, O’Brien, 2003; Valentine, 2004]. These studies recognize the importance of place in shaping children's urban practices, and a few studies have concentrated on children's daily lives in segregated 
contexts by highlighting the multiple spatial practices of children of different social and ethnic backgrounds depending on the neighbourhood in which they live [Karsten, 1998 ; O'Brien, 2003]. In addition, a few researchers while lamenting the scarcity of studies on children's social networks, have recently focused on the implications of children's decreasing spatial autonomy on their social network: they have showed how it resulted in a decline of social cohesion or in other terms in a sharpening of segregation patterns [Weller and Brugel, 2010; Karsten, 2010].

By building on these studies and by focusing on the case of a gentrified neighbourhood in Paris, this paper proposes to examine the children's practices and ways of living together, through the example of 9-11 year old schoolchildren ${ }^{v}$ in a state school in the Batignolles.

\section{The Batignolles neighbourhood, the school and the class}

The Batignolles, in the $17^{\text {th }}$ arrondissement of Paris, is widely considered as an "intermediary" neighbourhood [Bernard, 2004], both geographically and socially, compared to the working class Epinettes to the north of the Avenue de Clichy and to the bourgeois Monceau area to the south of the rail tracks (Fig. 1).

(Insert Fig. 1) 
A strong working class neighbourhood in the 1950's, the Batignolles subsequently suffered several decades of demographic and socio-economic decline, before a revival, starting in the 1990 's, with growth led by a back to the city movement of the middle classes. Today, with 25,500 residents, it is a socially heterogeneous area: executives and superior intellectual professions make up $52 \%$ of the employed population, side by side notably with workers $(6 \%)$, employees $(14.8 \%)$, and the retired $(18.7 \% \text { of the total households })^{\mathrm{vi}}$. This social diversity should be considered in light of the structure of the habitat: in this neighbourhood of modest five or six storey buildings, small apartments are still predominant; furnished rentals and social housing also allow accommodation for the less wealthy households. The structure of incomes highlights the social disparity of the neighbourhood's inhabitants, the incomes of the households in the first decile approximately being ten times greater than those of the last decile.

In addition, contrary to more central and trendier gentrified areas of Paris inhabited by young couples with no children or by single people [Clerval, 2008], it is a family neighborhood and more precisely a neighborhood of young children. Admittedly the households with children do not represent a greater share of the population in the Batignolles than in Paris or in the 17th arrondissement. But the children below 15 years old are overrepresented ( $15.3 \%$ vs. $14.4 \%$ in Paris) and $69 \%$ of the children (aged 18 or younger) are between 0 and 10 years old. These young children are very obvious in the daily life of the neighbourhood. On Saturday or Sunday mornings, the 
narrow pavements of the rue des Moines or the alleys of the covered Market can be extremely busy, quickly congested with prams and the patter of tiny feet. In fine weather the density of families and children in "Cardinet Park" (officially named Martin L. King Park and devoted to children of all ages) or in Batignolles Square (for younger children only) is extraordinary.

In this neighbourhood the children interviewed in this study all belong to a CM1 class (aged 9 to 11 ) in a state school ( 211 children in total, spread out over 10 classes from $C P$ (age 6-7) to CM2 (age 10-11)). vii Like the neighbourhood, this school is socially diverse. In attendance are children from very modest and from wealthier backgrounds. Coupled with this social diversity is a certain variety in the origins of the families, the school being made up of 21 different nationalities, where some children of French nationality also have foreign roots.

The class we chose consists of 27 children, 14 girls and 13 boys. These children live in different family setups: 14 children live with both their parents and 13 are from single parent or "reconstituted" families. As is the case for the whole school, the parents of this class have very diverse professions from lawyers, biologists, journalists, to caretakers, cleaners, taxi drivers, etc. All in all, working class children account for the majority (16 children out of 27 ) and the socio-professional composition of the class is the opposite of that of the neighbourhood. Added to this social diversity is a great cultural diversity, as 17 of the children have at least one foreign parent (Portuguese, 
Tunisian, Moroccan, Algerian, Turkish, Polish, etc.) and two of them are of Caribbean origin. More often than not these two dimensions (social background and cultural origins) overlap, but not always.

Geographically, 17 of the children live in the Batignolles and 10 of them live nearby, in the working class Epinettes area. These differences in location are very much linked socially: all but two of the upper middle class children live in the Batignolles. On the contrary, there are as many working class children living in the Batignolles as there are in the Epinettes (Fig. 1). For two of the children the family setup is more complex; the parents are separated, with one parent living in the Batignolles and the other in the Epinettes. In both cases the children spend more time at their mother's household, which for one is in the Batignolles, for the other in the Epinettes. ${ }^{\text {viii }}$ Within the class, we can distinguish three distinct groups: upper-middle class children who live in the Batignolles (9 children), working class children who live in the Batignolles (8 children), and working class children who live in the Epinettes ( 8 children ${ }^{\mathrm{ix}}$. In most cases, these children have lived in their households since birth and have attended the same school since the age of 7. But a few of them moved to the area more recently and have attended the school for a shorter period.

To understand the ways of living of these children, we have proceeded through two stages. Firstly, we asked them to draw their neighbourhood ${ }^{x}$. Then, we interviewed them all individually, for approximately fifteen minutes, based on a set of 7 photos of 
the Batignolles, among which were the local library, Cardinet Park, a shopping street, the market, the entrance to the metro, the neighbouring private school and a square situated towards the edge of the neighbourhood. These photos, which the children were invited to comment on, allowed us to appreciate their knowledge and representations of the neighbourhood, but also, through a series of questions linked to each photo, to collect broader information on their usage of the neighbourhood, their movements within and outside the area, and on their sociability. To complete the data, we also had a discussion with the children's teacher, as well as with a few parents.

\section{"The neighbourhood of happiness"?}

In general, the children know the Batignolles neighbourhood well. Most of them had no trouble in identifying the various photos. That was the case for all of the uppermiddle class children living in the Batignolles (of the two upper-middle class children living in Epinettes, just one of them recognised all the photos). It was also widely the case for the working class children of the area. Only half of the working class children living in Epinettes, though, were able to clearly identify all the places. The photos which proved the most problematic were those of the neighbouring private school, of the shopping street and of the square situated on the edge of the neighbourhood 
(which some children - including those living in the Batignolles - do not consider as part of their neighbourhood).

As well as being well-known, the Batignolles neighbourhood is also greatly appreciated, by both the upper-middle and working class children who live there. Within this positive feedback, which one of the (working class) children summarized by labelling his drawing "the neighbourhood of happiness", the children give particular weight to the presence of the parks, friends, sometimes family, and also, the proximity of shops:

[Do you like your neighbourhood?] "Well, yeah, we can do lots of things, there's a new park, there's a second park not far away, we don't go that often, we've got shops, it's good". (Paul, UMC)

"I like it, it's nice. I like to wander around, because sometimes I see people I know, so it's nice. I've got lots of friends who live next to me, I've got family, so it's nice. We see each other often, we have fun, there we go". (Antonia, WCF).

For some of the children, this positive feedback is often tempered with the appearance of some disadvantages. :

"Sometimes the people aren't very nice" (Martin, UMC)

"There are loads of bottles on the ground" and "sometimes, there are too many fights in the street". (Jessica, WCF)

The analysis of the usage of the gentrified Batignolles by the children reveals other differences. Some children clearly make great use of this socially diverse space: they often go to shops and markets, they regularly visit the library, they practise sporting and artistic activities locally, etc. Conversely, other children, who do not have these 
habits, make very little use of the neighbourhood. In addition to this quantitative criterion, a qualitative analysis allows to distinguish the nature of the children's practices: some children regularly visit the public areas of the Batignolles (the shops, the market or the parks), whereas others are more likely to be found in the library, the local cinema, or taking part in one of the extra-curricular activities organised by the school on Wednesday afternoons. Furthermore, according to the children, the usage made of this neighbourhood is more or less strongly defined by the parents, who may or may not accompany them in their movements around the area. Finally the children also partake in a range of activities outside of the Batignolles, which gives a purpose to what they do - or cannot do - within the Batignolles. For example, some children are involved in other clubs (sporting, musical, etc. ${ }^{\mathrm{xi}}$; other children, or even the same children, visit Paris' museums; others, still, will be regular visitors to nearby shopping centres, etc.

More precisely, the upper-middle class children living in the Batignolles tend to have an intense and multiple usage of the neighbourhood. This is the case for 5 out of the 9 children who belong to this type of family. For all the children, this usage is supervised by their parents and is accompanied by activities and "specific" outings outside the neighbourhood: learning music at the Conservatoire; visiting museums in Paris; going to Monceau Park situated in the adjacent "bourgeois" neighbourhood... Three other children from this type of family also go to the shops, the library or the cinema, often frequently, but do not partake in any activities near their homes. These children, less 
"anchored" in their area, are characterised by a significant social life - made up of outings and activities - outside the neighbourhood. The final child in this category has a far more limited usage of the neighbourhood, and in particular of the public spaces, and his local activities (Wednesday activities, catechism) are strongly supervised. This is undoubtedly in no small part due to his living in the area with his mother while he spends every other weekend at his father's house (with a garden) in the suburbs with his half-siblings. ${ }^{\text {ii }}$

Within the population of working class children living in the Batignolles, two subgroups become apparent. Half of them has an under-developed usage of the neighbourhood, essentially limited to going to the shops. These children do not visit the library, barely go to the cinema and do not partake in activities (sporting or cultural) in the neighbourhood (considered too expensive by one of them), or outside it. The other half, on the contrary, is characterised by a considerable usage of the neighbourhood: the children regularly go to the shops, the market and the cinema, less often to the library, and some of them partake in the organised Wednesday activities and the catechism classes given in the neighbouring private school. In this second group, some of the children also have activities going on outside the Batignolles.

Finally, the working class children living in the Epinettes very rarely make use of the Batignolles. They never (or rarely) go to the area's shops (because their parents do 
their shopping elsewhere), they do not visit the cinema or the library and they do not partake in other activities, in that area or anywhere else. In other words, they live very much "at a distance" from the gentrified neighbourhood, not only geographically but also socially. In this group, two girls, who both indulge in relatively distinctive activities outside the Batignolles neighbourhood (dancing, tennis, chess), and one boy, who attends catechism classes, do, however, have a more extensive usage of the Batignolles.

The socially diverse Batignolles neighbourhood is therefore occupied in a very unequal way by the children of the class. Comparatively, Cardinet Park appears more of a shared space.

\section{"Cardinet Park": a shared space}

"Cardinet Park", a 4 hectares park opened in 2007, consists of play areas for small children, medium-aged children and adolescents, a basketball court, a clay football pitch, a skate park, a wall for ball games and various green spaces. It acts as a linking area between the Batignolles (to the south-east) and the working class areas of the north of Paris, and in particular the Epinettes.

Very often referred to as the favourite place in the neighbourhood, for both Batignolles and Epinettes children, or as the place which they would choose if they 
were to take one photograph of their neighbourhood, this park is greatly appreciated by the children in the class, "because it's big, there are lots of people, there are lots of friends" (Jessica, WCF), "because there's noise, there are games, there's lots of things" (Samantha, WCF), even if some often point to there being "too many people" or "too many older kids". It is also an area visited by all the children interviewed, whether it is mainly at weekends, sometimes on Wednesdays, rarely during the rest of the week, after school, or even during the holidays. But this border space is not used with the same regularity by everyone. Where some children are there "every Saturday and Sunday" (Paul, UMC) or "more than once a week" (Jessica, WCF), others conversely go "not very often" or "not much", like Olivier (UMC) who prefers to spend his weekends playing with his "little brother" in his father's garden in the suburbs.

This varied usage is first and foremost related to the children's gender. Accordingly, all of the boys in the class use the park very regularly, with the exception of Olivier. This intense usage is not shared by the girls, as 6 (out of 14) of them cannot be found there regularly. Cardinet Park appears in fact to be a more regular haunt of working class children than of upper-middle class children (13 out of 16 claim to go there "very often", compared to 7 out of 11 in the other category). Unlike the gentrified neighbourhood of the Batignolles, it also comes across as a more working class space, where working class children and adolescents, more often present and in greater numbers, "set the tone locally" [Chamboredon, Lemaire, 1970]. This is revealed in the discussions held with some of the upper-middle class children's parents: 
"Batignolles Park, it seems to have a lot of people in it, and as a result, it's not great" (Mother of Lou)

"It's great to have a park, a green space. (...) And it's wrecked by people who are so out of control that they vandalise public property. They've just broken a building which was for toilets. They broke everything in the building. There was lots of violence, and damage to material in the park. It's terrible". (Mother of Olivia, who also refers to the "bad company" in the park).

Added to the differences in regularity are other distinctions which relate to the how the children get to the park. Most of the time the children go to Cardinet Park accompanied by one or both of their parents, usually the mother. But nearly half of the children often go to the park without parents. Some go with friends, others (or the same children on different occasions) with an older brother, an older sister or a cousin, and some even go alone. These different configurations are far from random, as the following table shows:

(insert Fig. 2)

Amongst the upper-middle class children, visits to the park are always supervised, by parents or by friends, except in one case (a boy). And for some of them, the use of this space is only allowed under parental supervision. This strong regulation appears closely tied to the impressions that some parents have of this place:

[Do you ever go to Cardinet Park alone?] "No, never, because my mother says it's not great there; sometimes they say it's full of scum". (Paul, UMC)

On the contrary, working class children will more readily visit Cardinet Park without their parents. If some of these children will alternatively go with parents or friends, in 
two cases this is the only way they get to the park. In addition, within this group, two children - again, two boys - sometimes go to the park alone.

Within the park, the children do numerous activities: soccer, basketball, tennis (Paul, UMC), scooter, roller-skating, rollerblading (Constantin, UMC), badminton and scooter (Jessica, WCF), jogging (Cindy, WCF), etc. But more than just a playing field, Cardinet Park is a place where the children meet their friends. More often than not, these are classmates or school friends. But they can also be close neighbours, or friends from primary school (who subsequently went to another school in the area), or even, more exceptionally, friends they have met in the park. In some cases, cousins - who also live in the neighbourhood or elsewhere in Paris - replace or complement the friends.

Like the school, and more than the gentrified neighbourhood, this haven of child sociability is a space where children from different social backgrounds rub shoulders with each other. But in order to understand more precisely how this mix works between upper-middle and working class children, we must first examine their sociability networks and habits. 


\section{From places to connections: the children's sociability}

The information gathered from the discussions with the children and their teacher allows us to gauge both the interpersonal affinities of the children in the class as well as their sociability outside school, in their homes, in Cardinet Park, in the Batignolles neighbourhood and beyond.

In the class we observe "a nice mix of children" [Ball, Vincent, Kemp, 2004]. Of the 27 children, 22 of them have affinities with at least one child from a different social background to their own. Only 3 (working class) children have affinities uniquely with one or more child from the same background as their own, and two other (uppermiddle class) children do not have very developed social relations with the other children of the class. This social mix does, however, appear better established amongst upper-middle class children than their working class peers. In the first category, 4 children have "mixed" relationships, shared between upper-middle and working class children, and 5 children have relationships exclusively or predominantly with working class children. In the second category, 9 children have relationships predominantly or exclusively with working class children, 3 children have mixed relationships and 4 children have relationships mainly with upper-middle class children. In this domain, residential location is not a discriminating factor. Working class children whose "school friends" are mainly working class are certainly more often those who live in the Epinettes. But it is not the case of all the Epinettes 
children, and two of the three working class children who have affinities solely with other working class children live in the Batignolles. Similarly, being a girl or being a boy is not a determining factor in the social layout of the school friend network, neither in the first category nor in the second. Unsurprisingly, however, the children's affinities are very gender orientated: inside or out of the classroom, boys are friends with boys, and girls are friends with girls.

These relationships based at school are often continued beyond the school walls, in the children's homes or in Cardinet Park, to different extents depending on the child. The boys tend to meet their classmates in the park. Girls are partial to this meeting place too, but are more likely to invite their friends round to their homes than the boys, for a snack, a birthday or a pyjama party. Equally, upper-middle class children are more likely to invite their school friends to their home than working class children, in part because the former category have homes more suited to receiving guests than the latter. But this propensity to invite is also undoubtedly a result of some of the parents' desire to bring the social relationships of their children into the home, and therefore control them. For example, Olivier (UMC) frequently invites round - a little too frequently for his mother's liking - his working class friends, who mostly live in the Epinettes, yet he never goes to their homes. Similarly, Lou (UMC) invites Cindy (WCF) (who also lives in the Epinettes) to her home, but does not pay her any visits in return. ${ }^{\text {iii }}$ 
For most of the children, these school friends, whom they meet just as often outside of school, form their principle network of relationships. But in the Batignolles or sometimes outside, the children often have other relationships: primary school friends attending another state school in the neighbourhood, friends met through various activities, neighbours they bump into, or even - although very rarely - friends from the neighbouring private school (out of the 27 children in the class, only 3 have friends from this private school). In addition, several children have cousins - in their neighbourhood or elsewhere in Paris - with whom they play regularly, in their homes or in Cardinet Park, or whom they visit (this is the case for 8 out of the 16 children from working class families, and only 3 out of the 11 children from upper-middle class families).

Following the trends of their parents [Héran, 1987], upper-middle class children are more likely to accumulate friendships through their multiple activities [Karsten 1998]. And very often the relationships forged by these children outside their network of school friends, in the neighbourhood and beyond, involve children from the same social background, guaranteeing the return to a certain social equilibrium when compared to the school friendships, which are often with children from working class families. Such is the case for Jeanne, who has friendships at school with girls from working class families whom she meets at Cardinet Park or whom she invites to her home, and also has friendships with girls from the same social background as herself, who live in her building, and/or who attend the neighbouring private school, or who 
live outside the Batignolles but with whom she shares the same leisure activities. But this double trend for accumulation and social re-equilibrium is not followed by all the children of this category; in Paul we have an example of a child who has few relationships, at school or elsewhere.

In comparison, working class children have less varied interpersonal networks. What is more, they tend to mix with children from the same social background as themselves outside of school, and in particular with members of their extended families (cousins, etc.). Antonia is one such child; she is friends with Alissa (WCF) and Jeanne (UMC) at school, but only ever invites Alissa to her home ("We're always together, always inviting each other round"). As a further illustration, Sophie has two friends from working class families at school, Samantha and Cindy, and two friends from upper-middle class families, Lou and Olivia. But outside of school, Sophie only mixes with Samantha, in Cardinet Park (Cindy and Lou rarely go to the park and Olivia never does), and two other girls from working class families who are her neighbours. For some of these children this trend towards social introversion outside of school, encouraged by the small numbers of children from upper-middle class families in the park, by the greater proximity of the family, by the disinclination to invite home children from other social backgrounds, only serves to double the social segregation observable at school. Lilian (a boy's name in France) is a prime example of this phenomenon: at school his only friend is Thomas, a child from a working class family of Portuguese origin, like him. Outside of school he mixes with Thomas in Cardinet 
Park, and spends a great deal of time - in the park and at home - with his cousins, also of Portuguese descent. But once again these trends do not apply to all the children of this category, as is shown by Jessica's friend network and sociability. She, like Lilian, lives in the Batignolles. At school Jessica is friends not with girls from working class families but with those from upper-middle class backgrounds. And outside of school, Jessica regularly visits their homes, she equally invites them to hers, and they also meet up in Cardinet Park.

The networks and sociability of the children, at school or outside, are therefore differentiated, between children of working class families and children of uppermiddle class families, but also within these categories. Far from being a simple reflection of geographical distance and proximity (between the children's homes), the varied combinations observed here point to more global trends of social diversity, or, conversely, social introversion.

\section{Openness to social diversity and introversion}

The joint acknowledgement of the children's connection to places, in Cardinet Park, but also beyond (through their activities and outings) and the links between themselves, in school and outside, highlights different ways of "playing" with the social diversity of the neighbourhood. 
On the whole upper-middle children in the Batignolles are typified by a real social openness to working class children. In line with the school choices of their parents, who opted for the neighbourhood's state school, these children have diverse social relationships and make real use of the different spaces in their neighbourhood. But this social openness, which is equally common amongst girls and boys, is strongly supervised by the parents. This parental supervision takes many forms: in accompanying the children in their usage of the neighbourhood and in particular of Cardinet Park, in the fact that the children are more likely to receive other children in their homes than they are to meet them in the park, and in the fact that the children are often signed up to "distinctive" activities outside of the neighbourhood. In other words, everything is in place to facilitate and encourage social diversity for these children, but these mechanisms simultaneously ensure it is controlled and nonexclusive. Behind these general trends, differences are to be found within this category of children. Certain boys, for example, with absent fathers and working mothers, are less regulated in their usage of the neighbourhood and Cardinet Park, as well as in their relationships. Another example, from the other side, is Olivia; she rarely meets children from working class families outside of school and has a very limited and supervised use of the neighbourhood. She does not take part in the activities organised at the school on Wednesdays, she does not go to Cardinet Park, and her nanny systematically accompanies her in all her movements within the area. 
Her mother expresses a critical and disenchanted view of the neighbourhood, and her social life is organised for her very much outside of the area.

Amongst working class children, two distinct categories become apparent. On one side are children who, through their usage of the Batignolles and Cardinet Park, and through their relationships, show a certain openness to social diversity, which appears less structured for them than it is for upper-middle class children. On the other side are children for whom social diversity is very limited, and who, in some cases, are characterized by a strong social introversion towards children of other backgrounds. The latter category, who have little or no contact with their classmates from upper-middle class families, who make almost no use of the gentrified Batignolles, are those who come from the most underprivileged households (their parents are unemployed, clothes-makers, cleaners...) and who, for this reason, live more often than children from the first category, but not always, in the Epinettes. Within the first sub-category, is a unique group of children, who all live in the Batignolles, and who combine an openness to social diversity with a strong cultural introversion. Antonia is one such child, as she mixes with upper-middle class children, makes extensive use of the gentrified neighbourhood and Cardinet Park, and yet she also attends catechism classes in Portuguese, spends a great deal of time with her Portuguese cousins who live nearby and speaks Portuguese with her parents at home. 


\section{Conclusion}

In the gentrified Batignolles neighbourhood there is a real mix between the working class children and the upper-middle class children (or, more accurately, between the working class children and the upper-middle class children whose parents have chosen to send to the local state school). In other terms, the children display a strong "goût des autres" compared to the limited interactions between adults from workingclass and from upper-middle class backgrounds, which several studies on gentrified neighbourhoods have highlighted [Simon, 1995; Butler, 2003; Lehman-Frisch, 2008]. Thus, the observation of the children's practices and of their ways of living together in gentrified neighbourhoods allows to highlight other ways of living together in these neighbourhoods and to reveal understudied aspects of the gentrification processes.

On the whole, contrary to the results brought forward by most studies on social mix (from Chamboredon and Lemaire [1970] to Launay [2011]), this paper highlights that social mix is not exclusive of social relationships between individuals of different social backgrounds ${ }^{\mathrm{xiv}}$.

But this social mixing comes in many different forms in the school, in Cardinet Park, and in other areas of the neighbourhood. In other words, there is no obvious continuity in the cohabiting relationships between the children from different social backgrounds, at school or in the wider area. For example, some children from uppermiddle families cohabit in a privileged way at school with children from working class 
families, but blend more willingly with children from the same social background as their own at home, in the neighbourhood or beyond. The same is true for working class children. These results show that it is necessary not to confine the analysis of children's co-existence to the school environment, as is usually the case of the studies of sociology of education (Van Zanten, 2009) and of gentrification. At the same time, they prove the importance for studies on children of analysing "the relationship between children's social networks at school and in the neighbourhood" [Karsten, 2010: 4]; like Lia Karsten has underscored recently, this is still a largely underresearched focus in Children's Studies, which should obviously be developed.

What is more, our study shows that this social mix does not affect all the neighbourhood's children equally, and can take a different form from one child to the next (including through parental supervision). More precisely, it appears that these children's rapport with social diversity varies according to their place of residence, between boys and girls, between working class families and upper-middle class families, and, also, within these two categories ${ }^{\mathrm{xv}}$. To better understand these differences, but equally to see how the co-existence relationships of the children of this gentrified neighbourhood structure the co-existence relationships of their parents, it would be useful to compare these children's experiences of social diversity with the co-existence relationships of their parents and with their views on social diversity. This is one of the aims of the next stages of this research. 
Translated from French by George McGairl. 


\section{References}

Atkinson, R. and Bridge, G. (ed.) (2005) Gentrification in a global context: the new urban colonialism. Milton Park: Routledge.

Authier, J.-Y. and Bidou-Zachariasen, C. (ed.) (2008) La gentrification urbaine. Espaces et Sociétés, 132/133.

Bernard, L. (2004) Le XVIlème arrondissement de Paris : des cicatrices profondes, une mixité introuvable. Unpublished thesis. University René Descartes-Paris V.

Butler, T. with Robson, G. (2003) London calling: the middle classes and the remaking of inner London. Oxford: Berg Publishers.

Chamboredon, J.-C., Lemaire, M. (1970) Proximité spatiale et distance sociale. Les grands ensembles et leur peuplement. Revue Française de Sociologie, XI (1), 3-33.

Chawla, L. (2002) Growing Up in an Urbanizing World. Paris and London: UNESCO and Earthscan.

Christensen, P. and O'Brien, M. (eds) (2003) Children in the City: Home, Neighbourhood and Community. London: Routledge.

Clerval, A. (2008) La gentrification à Paris intra-muros : dynamiques spatiales, rapports sociaux et politiques publiques. Unpublished thesis. University Paris 1.

Collet, A. (2010) Générations de classes moyennes et travail de gentrification. Changement social et changement urbain dans le Bas-Montreuil et à la CroixRousse, 1975-2005. Unpublished thesis. University Lyon 2.

Danic, I., Delalande, J. and Rayou, P. (2006) Enquêtes auprès d'enfants et de jeunes : Objets, méthodes et terrains de recherche en sciences sociales. Rennes: Presses Universitaires de Rennes.

Dansereau, F. (1985) La réanimation urbaine et la reconquête des quartiers anciens par les couches moyennes: tour d'horizon de la littérature nord-américaine. Sociologie du Travail, 21 (2), 191-205.

Glass, R. (1964) Introduction : Aspects of change, in : Center for Urban Studies (Ed.), London : Aspects of Change. London : McKibbon and Kee, XII-XLI.

Héran, F. (1987) Comment les Français voisinent, Économie et statistique, 195, 43-59. 
Holloway, S., Valentine, G. (2000) Children's Geographies: Playing, Living, Learning. London, New York: Routledge.

Karsten, L. (1998) Growing Up in Amsterdam: Differentiation and Segregation in Children's Daily Lives, Urban Studies, 35 (3), 565-581.

Karsten, L. (2003) Family Gentrifyers : Challenging the City as a Place Simultaneously to Build a Career and to Raise Children, Urban Studies, 40 (12), 2573-2584.

Karsten, L. (2007) Housing as a Way of Life : Towards an Understanding of MiddleClass Families' Preferences for an Urban Residential Location, Housing Studies, 22 (1), 83-98.

Karsten, L. (2010) Children's Social Capital in the Segregated Context of Amsterdam: An Historical-Geographical Approach, Urban Studies, 1-16.

Launay, L. (2011) Les politiques de mixité par l'habitat à l'épreuve des rapports résidentiels. Quartiers populaires et beaux quartiers à Paris et à Londres. Unpublished PhD thesis. University of Paris Ouest-Nanterre-La Défense.

Lees, L., Slater, T. and Wyly, E. (2008) Gentrification. London and New York: Routledge.

Lehman-Frisch, S. (2008) Gentrifieurs, gentrifiés: co-habiter dans le quartier de la Mission (San Francisco), Espaces et Sociétés, 132/133, 143-160.

Lehman-Frisch, S., Authier J.-Y., Dufaux, F. (2012), 'Draw me your neighbourhood': A gentrified Paris neighbourhood through its children's eyes, Children's Geographies, 10 (1), 23-40.

O'Brien, M., Regenerating Children's Neighbourhoods: What Do Children Want?, in: Christensen, P., O'Brien and M.(eds), Children in the City: Home, Neighbourhood and Community. London: Routledge, 143-161.

Oberti, M. (2007) L'école dans la ville: Ségrégation, mixité, carte scolaire. Paris: Les Presses de Sciences Po.

Simon, P. (1995) La société partagée. Relations interethniques et interclasses dans un quartier en rénovation. Belleville, Paris $X X X^{\mathrm{e}}$, Cahiers internationaux de sociologie, XCVIII.

Sirota, R. (dir.) (2006) Eléments pour une sociologie de l'enfance. Rennes: Presses Universitaires de Rennes.

Valentine, G. (2004) Public Space and the Culture of Childhood. Ashgate: 2004. 
Van Criekingen, M. (2008) Réurbanisation ou gentrification ? Parcours d'entrée dans la vie adulte et changements urbains à Bruxelles, Espaces et Sociétés, 134, 149-166.

Van Zanten, A. (2009) Choisir son école : Stratégies familiales et médiations locales. Paris: Presses Universitaires de France.

Vincent, C., Ball S. (2006) Childcare, Choice and Class Practice. London: Routledge.

Weller, S., Bruegel, I. (2009) Children's 'Place' in the Development of Neighbourhood Social Capital, Urban Studies, 46 (3), 629-643 
Illustrations:

Fig. 1: The Batignolles, a gentrified neighbourhood of Paris

Fig. 2: Whom do the children go to the park with?

' Le goût des autres (The Taste of Others in English) is a French film directed by Agnes Jaoui [1999] which deals with the relationships between individuals of different social backgrounds with different "cultural" tastes.

ii In this article, the notion of social diversity refers to the presence of socially differentiable peoples within a certain space. It does not prejudge the nature of the relationships between these peoples.

iii This neighbourhood constitutes one of the fields of study of ongoing research, financed by the Caisse Nationale des Allocations Familiales, on cohabitation relationships in gentrified "family" neighbourhoods, in Paris, London and San Francisco.

iv In France, and more widely in francophone social sciences, this meagre interest in children is not exclusive to works on gentrification: there are relatively few works associated with children [Sirota, 2006] and in particular very few studies on their urban habits [Danic, Delande, Rayou, 2006].

${ }^{v}$ We have chosen to focus on this age range because studies showed that children start to be more independent in their mobility in the neighbourhood when they reach the age of 8 years old [Danic, Delalande, Rayou, 2006]. In addition, we wanted to investigate their practices before they enter Middle School (11-12 years old) because middle schools are less often located in the neighbourhood of their homes.

${ }^{v i}$ The data mentioned in this section are extracted from the 2007 INSEE Census. They refer to the "Batignolles" IRIS (census tracts) number 1 to 6, 12 and 13 and the two "Epinettes" IRIS number 2 and 6, which as a whole correspond to our study area. The perimeter of the latter is smaller than the "Batignolles" district defined by INSEE, which is composed of 16 IRIS.

vii In France, state primary school admissions are based around local catchment areas, meaning they are, by definition, neighbourhood schools. In order to gauge the extent of possible 
avoidance of the state school system by certain families, and the variations this may lead to in their practices and representations of the neighbourhood, we have also investigated, within the bounds of our research, children from a private school in the same neighbourhood. In this article, these children are not taken into account.

viii Equally, two other children live in the Batignolles neighbourhood with their mothers and regularly spend the weekends with their fathers in the Parisian suburbs.

${ }^{\text {ix }}$ Two more children are from middle-upper middle class families and live in the Epinettes.

${ }^{x}$ See Lehman-Frisch, Authier, Dufaux [2012].

${ }^{x i}$ As Lia Karsten has shown in another context [Karsten, 1998], the activities undertaken outside of the neighbourhood are socially differentiated: 6 of the 9 middle class children living in the Batignolles are involved, compared to only 3 of the 8 of the two working class categories of children (Batignolles and Epinettes). There is also a clear sex divide within these activities: 5 of the 6 working class children in question are girls.

xii The two other children (two girls) from upper-middle class families who live in the Epinettes also have a limited usage of the Batignolles.

xiii According to the teacher, Lou's mother would prefer her daughter to invite another girl in the class (Olivia (UMC)) home, rather than Cindy.

xiv This study does not aim to analyze the impact of these interactions on the social construction of children.

${ }^{x v}$ This rapport varies also according to the cultural origin of the children, as shown by the case of Antonia. But as regards the Parisian neighbourhood of the Batignolles, this is not a determining factor. The "cultural" (or "ethnic") aspect certainly plays a more important role in the other gentrified neighbourhoods which we have chosen for our study (in London and San Francisco) in the structuring of cohabitation relationships between children. 